\title{
EDITORIAL
}

Translated version

DOI: http://dx.doi.org/10.1590/So034-759020190301

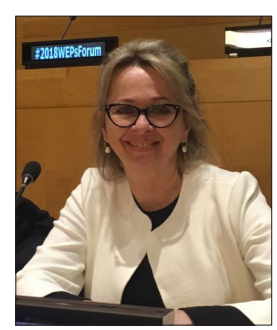

MARIA JOSÉ TONELLI Editora-chefe

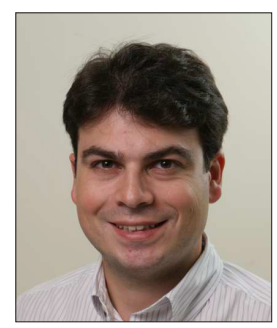

FELIPE ZAMBALDI Editor-adjunto

\section{MARKETING, CONSUMPTION, AND IDENTITY}

New times bring new themes. This issue includes three unconventional articles in the marketing field resulting from a partnership with two events: the "International Social Networks Conference" (Isonec) held at Fundação Getulio Vargas, School of Business Administration of São Paulo (FGV EAESP), and organized by Professor Eliane Pereira Zamith Brito; and the "Marketing Meeting" (EMA) organized by the National Association of Postgraduation and Research in Administration (ANPAD). The first article, by Maria Carolina Zanette, Izidoro Blikstein, and Luca M. Visconti, discusses Internet memes and their connections to consumer research. The second article, by Marcos Erbisti and Maribel Carvalho Suarez, deals with the anticonsumption discourse on the Internet; and the third, by Natália Contesini dos Santos and Severino Joaquim Nunes Pereira, discusses masculinity and consumption in new barbershops, showing that, in these spaces, the construction of masculinities occurs in the relationship between clients and service providers.

It is worth remembering the classic book by Paul Du Gay (1996) on this last theme, Consumption and Identity at Work, which discusses how goods and services shape identity in the consumer society. The relationship between consumption activities and social status was pointed out by Veblen in 1899 as the consumption behaviors of the "new rich." Authors such as Bourdieu (2007), Baudrillard (1991), and Bauman (1998) have discussed "consumption as a strategy of distinction" (Gambaro, 2012). However, these authors (except for Bauman) neither witnessed nor discussed the rise of the network society, the omnipresence of the Internet, and the dangers of a (un)sustainable society that can lead to anticonsumption and the trend of thrift shops among the youth. However, part of the literature on consumer behavior has been addressing the phenomenon of extending the identity of individuals to the goods and services they consume in the context of a digital world (Belk, 2013), an issue that has been repeatedly addressed by the Consumption Culture Theory (CCT). We hope these articles help clarify these interrelationships at the present moment.

This issue is completed by an article by Hildo Meirelles de Souza Filho, Carlos Ivan Mozambani, and Bruno Varella Miranda, "Mutual Commitments in the Governance of Trade in Vegetables in Serra Fluminense." The Perspectives section discusses the theme of Teaching and Research in People Management in Brazil. It includes an article by Wilson Aparecido Costa de Amorim, Graziella Maria Comini, and André Luiz Fischer, which is focused on people management and human resources, and the article "Post-heroic Leadership: Current Trends and Challenges for Leadership Education," by professors Felipe Sobral and Liliane Furtado, emphasizing the current context and challenges in leadership teaching. In the Book Recommendation section, Valdenildo Pedro da Silva lists several books on the topic “Circular Economy: A New Look for Sustainable Business."

Enjoy reading!

Maria José Tonelli' | ORCID: 0000-0002-6585-1493 Felipe Zambaldi ${ }^{1}$ | ORCID: 0000-0002-5378-6444

${ }^{1}$ Fundação Getulio Vargas Escola de Administração de Empresas de São Paulo, São Paulo, SP, Brazil

\section{REFERENCES}

Baudrillard, J. (1991). A Sociedade de Consumo. Portugal: 70th Edition.

Bauman, Z. (1998). Mal estar na Modernidade. Rio de Janeiro, RJ: Jorge Zahar Editors.

Belk, R.W.(2013). Extended Selfin a Digital World.Journal ofConsumerResearch, 40(3), 477-500. doi:10.1086/671052 Bourdieu, P. (2007). A Economia das Trocas Simbólicas. São Paulo, SP: Perspective.

Gambaro, D. (2012). Bourdieu, Baudrillard e Bauman: O Consumo como Estratégia de Distinção. Revista Novos Olhares, 1(1), 19-26. doi:10.11606/issn.2238-7714.no.2012.51444

Gay, P. Du. (1996). Consumption and Identity at Work. London, UK: Sage Publications. 